\title{
Oficerowie wciąż czerwoni? Filmowy wizerunek postkomunistycznych służb specjalnych na przykładzie Psów oraz Czerwonego Kapitana
}

W niniejszym studium porównawczym zajmę się dwoma filmami, których temat dotyczy działalności i sposobu funkcjonowania dawnych komunistycznych służb specjalnych po przełomie politycznym w Polsce po 1989 roku (po częściowo wolnych wyborach parlamentarnych z 4 czerwca) i na Słowacji (Czechosłowacji) w roku 1992, powstałej w wyniku podziału Czechosłowacji na dwa oddzielne byty państwowe - Czechy oraz Słowację. To ostatnie wydarzenie miało miejsce 1 stycznia 1993 roku (data oficjalnego złożenia podpisów głów państw), ale zgoda nań nastąpiła kilka miesięcy wcześniej, właśnie w roku 1992, który można nazwać w tym kontekście rokiem podziału czy rozpadu. Polski film Psy Władysława Pasikowskiego powstał dość szybko po przełomowych dla historii naszego kraju zdarzeniach, bo już w 1992 roku'; Czerwony Kapitan (cz. Rudý kapitán, sł. Červený kapitán), film słowacki, a właściwie słowacko-czesko-polski (jeśli spojrzeć na wiodących producentów) w reżyserii Michala Kollára dużo później, dopiero w roku 2016. Mimo dość odległej perspektywy czasowej uważam, że warto dokonać zestawienia akurat tych filmów, ponieważ wspólnym kontekstem jest wspomniany wyżej moment historyczny - czas przemiany, gwałtownego, stosunkowo krótkiego okresu, w którym wymienione kraje przeszły transformację ustrojową. Wynikłe z niego procesy i napięcia dotknęły bardzo mocno policji i służb specjalnych, w tym tzw. policji wewnętrznej. Stąd pomysł na charakterystykę wizerunku ich bohatera - w obu przypadkach „ubeka” ${ }^{2}$, który musi odnaleźć się w nowych okolicznościach politycznych, a przy tej okazji - na analizę porównawczą obu filmów.

* Uniwersytet Adama Mickiewicza w Poznaniu.

${ }^{1}$ Jego szeroką i burzliwą recepcję zebrał Marcin Adamczak w swojej książce Obok ekranu. Perspektywa badań produkcyjnych a społeczne istnienie filmu, Wydawnictwo Naukowe UAM, Poznań 2014, s. 240-244.

${ }^{2}$ Na polskim gruncie naukowym charakterystyką postaci „ubeka” zajęła się już Natasza Korczarowska-Różycka w: taż, Ballada o pobożnym ubeku, czyli polskie kino i polityka (1989_ 2015), „Dyskurs. Pismo Naukowo-Artystyczne ASP we Wrocławiu” 2016, nr 21, s. 242-271. 
Utwory te stworzyli reżyserzy należący do różnych pokoleń i na nieco innym etapie swojej kariery. Dla Pasikowskiego, urodzonego w 1959 roku w Łodzi reżysera i scenarzysty, prezentującego bardzo autorską postawę w ramach kina gatunków, Psy były drugim filmem pełnometrażowym w karierze, po powstałym rok wczesnej Krollu (1991) opowiadającym sensacyjną historię w kontekście nieprawidłowości w polskim wojsku. Dla Kollára natomiast, urodzonego w 1978 roku w Bratysławie, Czerwony Kapitan okazał się debiutem reżyserskim kogoś, kto zaczynał pracę w kinematografii nieco wcześniej od zawodu producenta (Po ślubie [Líbánky] Jana Hřebejka z 2013 roku, mistrza czeskiego kina). Kollár, produkując, reżyserując i pisząc z dwójką współautorów - Miro Šifrem i Anną Fifkovą - scenariusz, dopełniał raczej wieloautorskość całego przedsięwzięcia, ponieważ dokonywał wspólnie z pozostałymi adaptacji popularnej powieści pod tym samym tytułem.

Książka autorstwa Dominika Dána jest częścią mocno już rozbudowanej serii powieści. Dán pisze swoją bestsellerową serię powieści detektywistycznych już od 2005 roku i liczy sobie ona ponad dwadzieścia pozycji. Jej bohaterem jest policjant śledczy od spraw kryminalnych, Richard Krauz, który rozwiązuje zagadki zbrodni na Słowacji mniej więcej od wiosny 1988 roku (kolejno wydawane powieści nie ukazywały bohatera w ujęciu chronologicznym), czyli od momentu, kiedy w niektórych krajach środkowej i wschodniej Europy komunizm zaczynał mocno korodować, by kilkanaście miesięcy później dokonać swojego żywota, co potwierdziło się także poprzez wybory parlamentarne. Pisarz od wielu lat pracuje w policji jako detektyw w wydziale kryminalnym, a jego osiągnięcia $w$ tej dziedzinie zostały potwierdzone współpracą $\mathrm{z}$ tamtejszym ministerstwem spraw wewnętrznych. Autora, doskonale znającego realia opisywanych zdarzeń, interesuje nie tylko stworzenie ciekawego bohatera i emocjonującej fabuły, sprowadzonej do rozwiązywania kryminalnych zagadek. Wykreował postać poruszającą się w określonej przestrzeni - chaotycznej, istniejącej na gruzach starego porządku, zmieniającą się stopniowo wraz z upływem czasu, ale także na tle przemian społeczno-politycznych, będących wyrazistym zapleczem dla przygód głównego protagonisty. Inna sprawa, że można te kwestie zobaczyć lepiej, znając więcej książek z serii. Czerwony Kapitan $^{3}$ jest bowiem siódmą powieścią cyklu, a pierwszą z zaledwie kilku wydanych w Polsce. Trudno dociekać, dlaczego właśnie ta książka jako pierwsza została zaadaptowana na potrzeby kina; można zaryzykować tezę, że istotny był tutaj czas akcji, czerwiec 1992, zatem połowa roku,

\footnotetext{
${ }^{3}$ Dominik Dán, Czerwony Kapitan, przeł. Antoni Jeżycki, Media Rodzina, Poznań 2014.
} 
w którym dyskutowano o podziale Czechosłowacji, a właściwie ciągły proces, który się wtedy dokonywał. W filmie jest to czas nieco późniejszy, akcja zawiązuje się mniej więcej od końca lipca - widz zostaje o tym poinformowany przy pomocy czołówki utworu, przywołującej czas Igrzysk Olimpijskich w Barcelonie. Wróćmy jednak do dalszego zestawienia Psów i Czerwonego Kapitana.

\section{Przestrzeń}

W obu filmach mamy bardzo wyrazistego, choć zupełnie różnego bohatera. Aby móc się przyjrzeć tym postaciom, trzeba najpierw scharakteryzować nieco dokładniej czas i miejsce akcji tych utworów. W Psach jest to Polska 1989 roku, uwolniona od władzy komunistycznej, ale wciąż niepewna swego status quo. Trwa weryfikacja pracowników dawnych służb specjalnych, wykonujących dotąd swoją pracę wbrew dobru obywateli. Część z nich trafia do służby w policji, mającej służyć społeczeństwu obywateli, a nie - wyłącznie takiej czy innej władzy. Jako że nie można nowych struktur bezpieczeństwa budować od zera, spora grupa dawnych „ubeków”, jak ich powszechnie nazywano, zaczyna pracę pod szyldem nowej władzy i nowego porządku. Nie wszystkim się to podoba. Powszechnie stawiane jest pytanie: czy można zaufać komuś, kto dotąd odnajdywał się w zniewalaniu tych, których ma dzisiaj chronić? Umieszczenie akcji w środowisku byłych ubeków i policjantów w różnym stopniu wspierających dawny reżim spowodowało podwaliny pod specyficzny, symboliczny, ale i w dużej mierze dosłowny charakter przestrzeni filmu. Jest ona brutalna i zwulgaryzowana, pełna aktów przemocy fizycznej i słownej, miejscem powszechnego cynizmu i zdrady. To świat, gdzie instytucje służebne wobec obywateli pełne są wciąż osób, co do których charakteru i zachowania nie można mieć pewności. W budynkach policji palone są tajne dokumenty, korupcja jest niemal jawna, dochodzi też do eskalacji działań przestępczych. Ma tego świadomość bohater Psów, Franz Maurer (Bogusław Linda). Jest on wręcz emanacją zamieszkiwanej przez siebie czasoprzestrzeni. Trzydziestokilkulatek, oficer z dużym doświadczeniem i talentami, ale trudnym charakterem (świadczy o tym duża liczba pochwał i jeszcze większa liczba nagan, jakie otrzymał w czasie pracy), jest pozbawiony złudzeń, że nowa praca będzie się czymś różniła od dawnej. Początkowo można to traktować jako podejście pragmatyczne czy, w gorszym przypadku, cyniczne. Franz zna naturę zawodu, a zwłaszcza swoich kolegów, z których część, 
nie przeszedłszy pozytywnej weryfikacji, znalazła sobie zatrudnienie $\mathrm{w}$ sektorze prywatnym, najczęściej niestety $\mathrm{w}$ strukturach mafijnych, także zagranicznych. Często zresztą są one powiązane ze służbami zagranicznych wywiadów, zwłaszcza krajów sąsiednich. Nie chodzi jednak o wpływy polityczne. Pasikowski sugestywnie podkreśla, że ważniejszy stał się interes prywatny, nie zaś państwowy. O ten pierwszy natomiast można zadbać, przede wszystkim uczestnicząc $w$ handlu narkotykami. W filmie sugeruje się, że niektórzy przedstawiciele dawnych lub jeszcze istniejących służb wewnętrznych - rosyjskich, niemieckich (z NRD) oraz polskich - podległych władzom komunistycznym połączyły siły, by przejąć władzę nad rynkiem narkotykowym w Polsce. Reasumując: przestrzeń Psów to przestrzeń zdegradowana, miejsce, gdzie zostaje zawieszona albo co najmniej dramatycznie ograniczona sfera bezpieczeństwa publicznego i naturalnego charakteru prawnego instytucji, a zwłaszcza reprezentujących je funkcjonariuszy, którzy skupiają się często na działalności podporządkowanej celom indywidualnym, prowadząc ją w sposób przestępczy.

W Czerwonym Kapitanie sytuacja wygląda nieco inaczej. Jak wspominałem, autorzy filmu umieścili akcję w innym momencie dziejowym. Czechosłowacja Anno Domini 1992 nie rozpadła się jeszcze formalnie, choć w mentalności obywateli, a także działalności instytucji państwowych czy społecznych proces ten jest już mocno zaawansowany. W tym przypadku bohaterami są oficerowie policji z wydziału zabójstw, na których również ciąży odium lat służby dla władz dawnego systemu. Dawni funkcjonariusze, jak pokazuje to Michal Kollár za powieściopisarzem, świetnie odnajdują się w nowych realiach. Ich dotychczasowa władza i bezkarność w komunistycznej Czechosłowacji wydają się naturalnie przechodzić do struktur państwa demokratycznego (proces ten trwa już kilka lat). Z ich perspektywy, sądząc po wypowiedziach i czynach, można się spodziewać, że w podzielonym na dwa państwa dawnym kraju będzie podobnie. Podobnie jak w Polsce dwa, trzy lata wcześniej, trafiają albo do policji, albo zakładają firmy, czasami też zaczynają zajmować się działalnością polityczną. Novum, w kontekście filmu Władysława Pasikowskiego, jest ich silna, choć oczywiście toksyczna więź z Kościołem katolickim. Z jednej strony akcentuje się, że został on uwikłany siłą w zależność od komunistycznych służ bezpieczeństwa, z drugiej natomiast podkreśla, do jakiego stopnia w nowej rzeczywistości ta więź jest podtrzymywana, także przez tamtejszych hierarchów Kościoła, czerpiących zyski lub/i mających ochronę ze strony dawnych „ubeków”, ukrywających ich ewentualne niecne uczynki, odbywające się dzisiaj 
pod parasolem ochronnym dawnych, wciąż aktywnych służb. Trudno dociec, na ile taka wizja może mieć odzwierciedlenie w rzeczywistości historycznej. Można domniemywać, że jest wyolbrzymiona na potrzeby opowieści, ale z pewnością uczyniono ją bardzo sugestywną ${ }^{4}$. Stąd też chyba, podobnie jak w Psach, obserwujemy świat bardzo brutalny, skorumpowany, nieprzyjazny zwykłemu obywatelowi, pełen przemocy i okrucieństwa, który łatwo infekuje postronnych albo uderza w nich rykoszetem. Chwilami można odnieść wrażenie, że żadne spory nie są w nim rozwiązywane bez użycia siły. Dialog z kolegą czy rozmowa ze świadkiem są prowadzone w kontekście zależności jednej osoby od drugiej, przy pomocy gróźb, przemocy psychicznej lub nawet tortur. Policjanci są nie tylko zepsuci moralnie: widać też $\mathrm{w}$ ich poczynaniach znużenie, niechęć i obawę przed podejmowaniem spraw trudnych czy naruszających czyjeś terytorium wpływów. Grają znaczonymi kartami, łamiąc niechętnie ustalone pokątnie zasady. Są jednak wyjątki, czasami stać ich na bezinteresowną pomoc koledze, może nawet pozostają otwarci na przyjaźń. Do tego potrzeba jednak kogoś mniej uwikłanego w dawne układy, a zwłaszcza bezkompromisowego, trzymającego się nie tyle imperatywu etycznego, ile intelektualnego czy zasad profesjonalizmu. Taki jest główny bohater filmu, stosunkowo młody oficer Richard Krauz (Maciej Stuhr). Aby jednak przyjrzeć mu się dokładniej, zwłaszcza w kontekście postaci Franza z Psów, musimy zająć się wykorzystaniem przez obu reżyserów wzorców genologicznych, które znacznie wpłynęły na kształt głównych protagonistów tych filmów.

\section{Gatunek}

Psy Władysława Pasikowskiego mają za wzór kino sensacyjne w odmianie filmu policyjnego. Bohaterem jest stróż prawa ukazywany w środowisku innych sobie podobnych, a jego działalność to nie tylko praca polegająca na rozwiązywaniu kolejnych zagadek kryminalnych, lecz także skomplikowane interakcje z kolegami, z którymi musi negocjować lub

${ }^{4}$ Jeśli ktoś, zwłaszcza z polskich widzów, ma wątpliwości, czy twórcy filmu nie hiperbolizują ciemnej sfery życia naszych południowych sąsiadów z tamtego okresu, może sobie przypomnieć porwanie przez agentów słowackiego wywiadu SIS w 1995 roku syna prezydenta tego kraju - Michala Kováča juniora, noszącego imię i nazwisko ojca. Do dzisiaj podejrzewa się, że stali za tym ludzie podlegli ówczesnemu premierowi Słowacji, Vladimirowi Miečarowi. Obaj politycy byli wtedy w silnym konflikcie. 
wręcz walczyć o sposób prowadzenia śledztwa. Niewątpliwie gatunek ${ }^{5}$ ten jest w gruncie rzeczy kontaminacja, co jeszcze mocniej widać dzisiaj, $\mathrm{w}$ dobie powszechnej hybrydyzacji form rodzajowych i gatunkowych. Połączenie thrillera, filmu gangsterskiego i detektywistycznego jest wzorcowo zobrazowane filmem autora Operacja Samum (1999). Pasikowski odwołuje się do późnej odmiany tego gatunku, zwłaszcza amerykańskich cop movies z lat 70. XX wieku, czasów Francuskiego łącznika (The French Connection, 1971) Williama Friedkina i Serpico (1973) Sidneya Lumeta. Według syntetycznej opinii encyklopedycznej:

Policjant $\mathrm{w}$ tych f. [filmach - przyp. J. N.] to najczęściej samotny indywidualista, który świadom nieudolności systemu prawa zmuszony jest stosować metody nielegalne, stawiające go na granicy dobra i zła. Pojawia się motyw korupcji; alienację bohatera pogłębia wielkomiejska sceneria. F. [film] p. [policyjny] w tej postaci pełni funkcje rozrywkowa, jednocześnie jednak daje pesymistyczną wizję rzeczywistości, odzwierciedla niepokoje społeczeństwa doby kontestacji ${ }^{6}$.

Postać policjanta nigdy nie będzie tu jednoznacznie określona etycznie; musi się ona uciekać do zachowań poza granicami prawa nie tylko po to, aby upomnieć się o sprawiedliwość, lecz także, aby chronić swe dobre imię, a często zdrowie i życie. Sytuacja Franza Maurera w świecie przedstawionym Psów jest pod tym względem modelowa. Początkowe starcie z grupą przemytników samochodów i w jego wyniku śmierć trójki kolegów-policjantów są tylko wstępem do większej intrygi, za którą kryją się dawni partnerzy Franza ze służb specjalnych, nie zawsze pozytywnie zweryfikowani przez nową władzę. Ma miejsce konflikt z Olem (Marek Kondrat), byłym kolegą z SB, który obecnie wybrał życie po drugiej stronie barykady. Dla bohatera granego przez Lindę liczy się zarówno zadanie policyjne, jak i kwestia osobistego honoru, nadszarpniętego przez podwójną zdradę dawnego przyjaciela. Policjant w filmie tego typu zwykle kieruje się jakimś kodeksem - zwykle lojalności koleżeńskiej, wierności rodzinie, troską o najmłodszych itd. Czasami też budzi się w nim sumienie pod wpływem skrajnie dramatycznych wydarzeń, których jest świadkiem lub uczestnikiem. Zwykle zresztą stoi po stronie przegranych, do których - notabene - sam się najczęściej zalicza. Bohater Psów jest człowiekiem

${ }^{5}$ Najszerzej gatunek policyjny charakteryzuje w rodzimym piśmiennictwie Elżbieta Durys w swojej książce Amerykańskie popularne kino policyjne w latach 1970-2000, Wydawnictwo Uniwersytetu Łódzkiego, Łódź 2013.

${ }^{6} \mathrm{KW}$ (Katarzyna Wajda), hasło: policyjny film, [w:] Encyklopedia kina, red. Tadeusz Lubelski, Wydawnictwo Biały Kruk, Kraków 2003, s. 751. 
przegranym z wielu powodów: opuszcza go żona, a następnie młoda ukochana, która odchodzi do lepiej sytuowanego w półświatku Ola, dawny kolega zdradza go i wydaje na niego wyrok, wreszcie - w planie społeczno-instytucjonalnym - nowi przełożeni nie darzą go zaufaniem. Wydaje się, że Franz znalazł się w ślepym zaułku, zresztą jako widzowie przeczuwaliśmy to wraz z nim niemal od początku rozwoju wydarzeń. Nic dziwnego, że tym łatwiej przychodzi mu łamać prawo - z każdą chwilą ma coraz mniej do stracenia.

Już dawno zauważono, że w amerykańskich filmach o policjantach granica między prawem a bezprawiem została znacząco przekroczona. I to bynajmniej nie w latach kontrkultury, a już w dekadzie lat 30. XX wieku. Nic dziwnego, że kino światowe, uczące się gatunków przeważnie od Hollywood, z ochotą przekreśliło wspomnianą granicę. Z czasem postępowano pod tym względem coraz swobodniej. Jak zauważono: „Policjant ścierający się z siłami zła musi często korzystać z metod nielegalnych. W konsekwencji, by być skutecznym w walce z przestępcami, by nie ustąpić im pola, musi upodobnić się do nich - tym zaś, co go odróżnia, jest jedynie policyjna odznaka"7. Ale sytuacja ukazana w Psach idzie jeszcze dalej. To przykład filmu policyjnego, w którym praca organów ścigania właściwie nie jest już przedstawiana jako służąca dobru społecznemu. Jest raczej podrzędną wobec zaspokojenia indywidualnych celów - na przykład zemsty czy ocalenia honoru. Co ważne, sfery: zawodowa i osobista bohaterów kina policyjnego dość szybko w ramach rozwoju tego gatunku uległy przemieszaniu. Oznacza to ni mniej ni więcej, że coraz trudniej jest spoglądać widzom na przedstawicieli prawa jako ich reprezentantów, jak na osoby dbające o dobro ogółu. Dalsze konsekwencje ekranowe tej sytuacji cytowany wyżej Krzysztof Loska określa jako: „wdarcie się przemocy w idylliczną sferę prywatności, problem przeniesienia zła, z którym ma się do czynienia w pracy, w sferę osobistą - tu sprowadzający się do zniszczenia życia rodzinnego" ${ }^{\prime \prime}$. Oczywiście życie rodzinne czy prywatne bohatera Psów w żadnym stopniu nie wygląda na sielankowe, ale w innych okolicznościach społecznych czy historycznych mogłoby mieć taki charakter. Wydaje się, że zmiana ustrojowa w Polsce w 1989 roku przyniosła właśnie takie dramatyczne konsekwencje $\mathrm{w}$ ramach pracy i życia poza nią. Prawo często zostaje wyrugowane przez samosąd, osobiste porachunki górują nad profesjonalnym uprawianiem zawodu, który przecież z założenia ma charakter misyjny, o czym bohaterowie (a często także widzowie) kina

${ }^{7}$ Jacek Ostaszewski, Stużyć, chronić i..., czyli filmy o policjantach, [w:] Wokół kina gatunków, red. Krzysztof Loska, Rabid, Kraków 2001, s. 45.

8 Tamże, s. 49. 
policyjnego zdają się zapominać. W polskich warunkach trzeba dodać do tego odium niechęci i podejrzliwości, jakimi społeczeństwo obdarzało Milicję Obywatelską i Służbę Bezpieczeństwa do 1989 roku. Po upadku rządów komunistycznych nowe, analogiczne służby państwa demokratycznego musiały stopniowo pracować na zmianę wizerunku. Pasikowski pokazuje, że miał to być proces długotrwały i dramatyczny. Późniejsze losy filmu policyjnego, po epoce kontrkulturowej lat 70. XX wieku, przyniosły znaczące poszerzenie wzorca gatunkowego, który $\mathrm{w}$ jednej $\mathrm{z}$ odmian ewoluował w kierunku moralitetu. Według Loski:

Konflikt samotnego policjanta $\mathrm{z}$ coraz groźniejszymi psychopatami, seryjnymi mordercami, handlarzami narkotyków czy terrorystami, dysponującymi często koneksjami politycznymi bądź też ukrywającymi swe działania za fasadą legalnej przedsiębiorczości, nabierał cech konfrontacji dwóch światów moralnych. W logice rozwoju opowiadania nie chodziło już o dowody winy czy zgromadzenie materiału obciążającego, lecz o spektakularną karę, o zniszczenie przeciwnika. Mariaż indywidualizmu ze stanem frustracji społecznej zaowocował typem bohatera, podejmującego nieustępliwą walkę w obronie społeczeństwa w sprawach, w których instytucje oficjalne się mylą. Dlatego mógł lekceważyć przepisy i egzekwować sprawiedliwość na własną rękę?.

Film Pasikowskiego modyfikuje jednak i ten schemat, ponieważ, co już podkreślałem, jego bohater broni własnych racji, a jeśli upomina się o dobro wspólne, to tylko mimochodem. Zanim jednak dokonamy pełnej charakterystyki Franza Maurera jako specyficznego bohatera kina policyjnego trzeba jeszcze określić schematy gatunkowe, którymi posługuje się Michal Kollár.

Czerwony Kapitan czerpie obficie z literatury i kina noir oraz próbuje klasyczne konstrukcje przeszczepić na grunt opowieści o policjantach ze środkowoeuropejskiego kraju, żegnających się ze służbą dawnemu, komunistycznemu reżimowi, także - ze społecznym napiętnowaniem jako służalców złej władzy. To podwójne mapowanie jest dość karkołomne. Reżyserowi udaje się zachować wiele atrybutów tego gatunku. Film cechuje bardzo mroczny nastrój, wręcz fatalistyczne podejście nie tylko co do możliwości rozwiązania zagadki kryminalnej, lecz także powrotu społecznego ładu oraz przywrócenia sprawiedliwości. Śledztwo w sprawie śmierci osoby, w której ciele, odnalezionym przypadkowo po kilku latach, znaleziono gwóźdź wbity w czaszkę, przyjmuje nieoczekiwany obrót i coraz szerszy zasięg. Okoliczności śmierci wskazują na robotę czechosłowac-

\footnotetext{
9 Tamże, s. 61-62.
} 
kich służb specjalnych, a z nich wywodzą się niemal wszyscy ekranowi policjanci. Jak zatem $w$ tych okolicznościach prowadzić śledztwo? Czy śledczy nie prowadzą go we własnej sprawie? Wśród nich jest ten bardziej uczciwy i obiektywny, młodszy o kilka lat od pozostałych główny bohater. Piętno "czerwonego" dotyka go w o wiele mniejszym stopniu niż pozostałych, ale sympatii czy choćby szacunku ze strony zwykłych obywateli za wiele przy pierwszym kontakcie i tak nie zyskuje. Ważniejsze natomiast, że jest człowiekiem w matni, podobnie jak dawni protoplaści czarnych kryminałów. Nie może znaleźć właściwych narzędzi do oceny rzeczywistości, brakuje mu też stałych punktów odniesienia. Ani przyjaźń ani rodzina nie są w stanie w pełni się nimi stać. Są najczęściej ich namiastką. Ale reżyser, idąc śladem autora pierwowzoru literackiego, ma już dawno za sobą lekcje sztuki brane u Raymonda Chandlera i Dashiella Hammetta czy u filmowców-klasyków: Johna Hustona, Fritza Langa lub choćby Roberta Siodmaka. W filmach tych ostatnich pojawiał się często sposób obrazowania odrealniony, momentami wręcz oniryczny. Kollár postępuje inaczej, stawiając na realistyczną odmianę opowieści noir, dość wiernie starającą się dokumentować rzeczywistość materialną i społeczną (czy też tak ją odtwarzać). Jeśli chodzi o tematykę, to pojawia u tego artysty motyw korupcji politycznej, zarażenia złem instytucji państwa i, co pewnie jeszcze gorsze, Kościoła. Ma to swoje dobre strony - jako widzowie możemy uznać w tym kontekście wykreowany przez niego świat za wiarygodny.

Reżyser wraz z polskim operatorem - Kacprem Fertaczem oraz scenografem - Tomášem Svobodą nawiązują niekłamany kontakt z rzeczywistością którą opisuja a z którą wielu odbiorców konfrontowało się przecież jeszcze nie tak dawno na co dzień. Wygląd ulic, budynków, wnętrz, rodzaj ubiorów, jakie noszą postaci, harmonizuje zarówno z Bratysławą początku lat 90. XX wieku, jak i wieloma innymi dużymi miastami środkowej i wschodniej Europy. Miasto, zwłaszcza amerykańskie, w tego typu utworach bywało zazwyczaj molochem, pożerającym własne dzieci - zamieszkujących je niewinnych obywateli oraz przestępców. Było labiryntem, z którego trudno się wydostać. Kollárowi udaje się oddać ten charakter przestrzeni, mimo pomniejszonej skali, w jakiej się porusza i odmiennego kodu geograficzno-kulturowego. Słowacka stolica w Czerwonym Kapitanie odpycha niezgrabną architektura, odrapanymi murami, brzydkimi ludźmi. Czasem, gdy akcja przenosi się poza wspomniane miasto, nie możemy jako widzowie rozpoznać innych obszarów, tak niewiele się różnią od Bratysławy, choć nominalnie są odrębne. Postaci poruszają się w świecie, któremu niewiele już brakuje do określenia: locus 
horridus. Jednak ta zamierzona wizualna zgrzebność przestrzeni obraca się ostatecznie przeciw filmowi. Zaczyna nad nim ciążyć stosowany przez twórców weryzm. Zbyt duży nacisk położony na realizm przedstawiania i estetyczną dosłowność w połączeniu $\mathrm{z}$ dużą dawką przemocy dominują nad bohaterem, który staje się jeszcze jednym elementem fizycznego pejzażu tej historii. Nie wyrasta ani emocjonalnie, ani etycznie, ani choćby właśnie fizycznie ponad brudna, nieznoszącą urody i piękna przestrzeń.

Pamiętajmy, że dojrzały czarny kryminał, Chandlerowski z ducha, ukazywał politykę jako sferę życia podejrzana, nihilistyczna, w najlepszym razie obłudną. Pod tym względem Czerwony Kapitan jest bardzo reprezentatywny. Wspominałem już, że została tu przedstawiona ukryta symbioza niektórych hierarchów Kościoła katolickiego i dawnych oficerów służby bezpieczeństwa. Charakter i skala tych związków może budzić grozę. Kollár pokazuje, że dwie instytucje o sprzecznych celach i sposobach funkcjonowania mogą prowadzić haniebny dialog i współpracę. Tym samym, za autorem literackiego pierwowzoru, a także amerykańskimi protoplastami, przeprowadza dramatyczna, nieoczywistą krytykę społeczna, cechującą literaturę i kino noir. Za tym wszystkim kryje się - może kluczowa - także wzięta od klasyków chęć zburzenia upraszczającej obraz rzeczywistości granicy między dobrem a złem. Tu jest ona wyjątkowo nieostra. Przykładowo, tytułowy czerwony kapitan (Oldřich Kaiser), który specjalizował się w przesłuchaniach przy pomocy tortur, z jednej strony jawi się jako kochający dziadek, opiekujący się na emeryturze wnukiem, $\mathrm{z}$ drugiej - w tych samych niemal scenach jest walczącym na śmierć i życie niedawnym oficerem aparatu przemocy, który wciąż potrafi być bezwzględny i śmiertelnie niebezpieczny. Bardzo trudno wskazać w Czerwonym Kapitanie jednoznaczne ukaranie za zło, które ktoś wyrządził, nie mówiąc już o nagrodzie za dobro, do którego się przyczynił; to także wyraziste echo sztuki dawnych mistrzów i rzemieślników noir.

\section{Bohater}

Franz Maurer jest bohaterem, który zdaje sobie sprawę, że jest człowiekiem przegranym zarówno w sferze zawodowej, jak i prywatnej. Opuszczany i zdradzany przez bliskich i przyjaciół często podkreśla, że jego miejsce jest na „śmietniku historii”, że trzeba po nim „posprzątać”, że jego czas minął. Jak zauważono: „Linda gra «mężczyznę po przejściach», zgorzkniałego, broniącego się przed światem warstwą cynizmu i wulgarności, w gruncie rzeczy jednak delikatnego, wrażliwego i zachowującego gdzieś 
w głębi ślad dawnych ideałów"10. Część kolegów Franza zaczęła w nowych czasach bardzo dobrze prosperować; to ci, którzy dla pieniędzy potrafią odrzucić uczucia. Bohater natomiast znalazł się w tej grupie "psów", która zamiast tropić i zdobywać, podlega „odstrzałowi”, co oznacza albo metaforyczne określenie odsunięcia od wpływów i apanaży, na przykład w związku z weryfikacja, albo dosłowne decyzje o likwidacji przez grupy przestępcze, powiązane zwykle $z$ dawnymi lub aktualnymi kolegami z policji. Maurerowi bliższa jest postawa romantyczna, samotnego outsidera uparcie trzymającego się kilku wartości. Raczej nie wierzy już w sprawiedliwość zagwarantowaną przez instytucje; chce i musi wymierzać ją sam. Nie wierzy też w najważniejszy polski mit współczesności - mit „Solidarności", tej pisanej z dużej litery. Jednak w decydujących momentach spieszy z pomocą kolegom z policji, a tych którzy podnieśli rękę na dawnych "towarzyszy broni", często karze. Swoją bezkompromisową postawą ukształtował nawet tych, którzy jako nowi w zawodzie traktowali go podejrzliwie. Przyjaźń i odpowiedzialność w pracy, choć różnie interpretowane, wydają się drogowskazem moralnym. To ostatnie określenie wcale nie jest tu użyte przypadkowo. Bohater jest $\mathrm{w}$ istocie figura grzesznika $\mathrm{w}$ subwersywnej wersji moralitetu ${ }^{11}$, jakim są Psy. Paradoksalność użycia tej konwencji polega w filmie m.in. na tym, że Franz nie jest już alegorycznym Everymanem, lecz człowiekiem w określonym czasie i miejscu. Jednak nadal pozostaje bytem uniwersalnym, kimś, kto walczy ze soba, próbując zachować twarz. Kluczowa jest tu prawdopodobnie scena, w której Maurer decyduje się nie przystępować do narkotykowej mafii, lecz z nią - na małą skalę oczywiście - próbuje się rozprawić. Postawiony przed przymusem wyboru decyduje się, nie bacząc na konsekwencje, wybrać w zgodzie z wewnętrznym głosem, jeśli trudno w tym przypadku mówić o sumieniu. Czy nie przypomina $\mathrm{w}$ tym dawnego bohatera średniowiecznej przypowieści?

Próbując z kolei dookreślić charakter postaci młodego oficera policji Krauza z Czerwonego Kapitana, można odwołać się do kategorii moralnych obecnych również w czarnym kryminale. Nie ma tu takiej ich relatywizacji, jaką obserwowaliśmy w Psach; choć można się na pozór spodziewać, że i w tej czasoprzestrzeni relacje dobro-zło będą podlegać umowie społecznej. Stary, totalitarny system społeczno-polityczny zostaje zastąpiony nowym, z założenia demokratycznym i sprawiedliwszym. Kollár wybrał moment historycznego przełomu, aby nie było to jednoznaczne

${ }^{10}$ Mirosław Przylipiak, Jerzy Szyłak, Kino najnowsze, Wydawnictwo Znak, Kraków 1999, s. 180.

${ }^{11}$ Ciekawą interpretację filmu w perspektywie moralitetowej przedstawił wkrótce po premierze Piotr Lis w: tenże, Moralitet z klocków, „Kino” 1993, nr 5, s. 14-15. 
i łatwe. Postawił na płynność, ciągłą walkę sił starego i nowego porządku. W klasycznym modelu ta walka odbywa się także we wnętrzu człowieka. W jednej z pierwszych scen Richard Krauz informuje jedną z postaci, u której budzi dużą nieufność, że wstąpił do policji w 1985 roku, więc jeszcze w okresie mocnej pozycji komunistów, ale pracuje teraz w wydziale kryminalnym i nie ma z polityką nic wspólnego. „Dobry ubek i zły ubek w jednym" - mówi o nim wspomniana rozmówczyni. U młodego policjanta ewentualnych dylematów z tego wynikających nie widać, jest zdeterminowany, aby odkryć, kto stoi za zbrodnią sprzed kilku lat. Ale motywacji tego uporu nie znamy. Richard jest dla widza zagadka, podobnie dla kolegów z pracy. Budzi z czasem szacunek swoją nieustępliwością ale pozostaje nieodgadniony. Wydaje się, że w wielkiej konstrukcji powiązań, matactw, przestępstw jest mechanizmem, który zaczął działać samoczynnie. Próby kontroli nad nim powiększają tylko bilans ofiar. Pod tym względem konstrukcja głównego bohatera filmu jest analogiczna do pomniejszych, w większości negatywnych postaci. Dostrzegł to już Bartosz Żurawiecki w jednej z pierwszych recenzji:

\begin{abstract}
Autorzy rozmywają indywidualną odpowiedzialność za zbrodnie. Niby wszystkie drogi zaczynają w pewnym momencie prowadzić do osławionego oprawcy, tytułowego Czerwonego Kapitana, ale i on okazuje się wyłącznie trybikiem w machinie. Winę ponosi system komunistyczny, oskarżyć trzeba tych, którzy - ze strachu, z konformizmu, z wyrachowania - mu służyli ${ }^{12}$.
\end{abstract}

Charakter i ukształtowanie bohatera każą myśleć o roli przypadku, determinującym zachowanie osoby, która dostała się we władanie sił, których nie pojmuje, ale którym musi się poddać. Jednak w takim modelu często obserwujemy daremność ludzkich wysiłków. Fatalizm ten udziela się całej słowackiej (i czeskiej) rzeczywistości przedstawionej w filmie. I ona, i Richard Krauz są jego ofiarami. Za jakiś czas, jak pokazała historia najnowsza tego kraju, będą mogli poczuć się zwycięzcami, przekraczającymi polityczny determinizm. To jednak dotyczy już ludzi i rzeczywistości pozaartystycznej. Konwencja artystyczna filmu na razie na to nie pozwoliła.

Wracając jeszcze do filmu Władysława Pasikowskiego: czy rzeczywiście Psy zasłużyły na tak rozbieżne początkowo opinie, jakimi okazały się - z jednej strony - aprobata publiczności, masowo odwiedzającej kina wyświetlające w listopadzie 1992 roku i kolejnych miesiącach film oraz z drugiej - często krytyczny głos krytyki i elit kulturalnych, zarzucających utwo-

${ }^{12}$ Bartosz Żurawiecki, Czerwony Kapitan (recenzja), „Kino” 2016, nr 8, s. 83. 
rowi nihilistyczne podejście do ukazywanych na ekranie wartości? Słynna do dzisiaj i często cytowana wypowiedź Andrzeja Wajdy na temat Psów okazała się znamienna, ale nie do końca sprawiedliwa. W rozmowie z Tadeuszem Sobolewskim w 1993 roku polski reżyser mówił m.in.: „Pasikowski jako taki specjalnie mnie nie interesuje. Natomiast interesuje mnie jego publiczność. Bo on coś wie o tej publiczności, czego ja nie tylko nie wiem, ale może nawet nie chciałbym wiedzieć. Myślę, że ten film spekuluje na ludzkim rozczarowaniu, ludzkiej bezradności"13. Dziś widać, że cel Władysława Pasikowskiego był zgoła inny niż odwoływanie się do resentymentów. Raczej wyrażał swoim utworem poczucie, że nie wszystko, a może niewiele, się w wolnej Polsce udało. Podkreślał to Tadeusz Lubelski, pisząc w ujęciu historyczno-filmowym o reprezentacji „,kina bandyckiego":

W Psach odzywa się ten żal. W postawie autorów można odczytać rozczarowanie światem, którym nikt nie odpowiada za zło przeszłości; bluźniercze odśpiewanie "Janka Wiśniewskiego" to odpowiedź na zgodę na palenie teczek. Tak też było z bohaterem Lindy: rzucenie się w podejrzane interesy było oznaką zagubienia, maska cynika kryła rozpacz i tęsknotę za wartościami, jak zresztą bywa w amerykańskich filmach sensacyjnych, do których formuły nawiązywały utwory tej grupy ${ }^{14}$.

Film Władysława Pasikowskiego wyraża przede wszystkim nostalgię za jasnym i czytelnym podziałem ról społecznych w świecie tych ról pozbawionym. Odwołując się $\mathrm{w}$ paradoksalny sposób do formy moralitetowej ujętej w karby filmu policyjnego, chce przywołać wyraziste reguły sztuki w sytuacji ponowoczesnego utracenia znaków na mapie międzyludzkiego, społecznego terytorium, które - w tamtym momencie historycznym - powstania i prezentowania polskiej rzeczywistości przełomu politycznego, nowej mapy jeszcze nie stworzyło.

\section{Bibliografia}

\section{Druki zwarte}

Adamczak Marcin, Obok ekranu. Perspektywa badań produkcyjnych a społeczne istnienie filmu, Wydawnictwo Naukowe UAM, Poznań 2014.

Dán Dominik, Czerwony Kapitan, przeł. Antoni Jeżycki, Media Rodzina, Poznań 2014.

13 Andrzej Wajda, Pojedynek z dniem dzisiejszym. Rozmowa z Tadeuszem Sobolewskim, „Kino” 1993, nr 4.

14 Tadeusz Lubelski, Historia kina polskiego. Twórcy, filmy, konteksty, Wydawnictwo Videograf II, Chorzów 2009, s. 569. 
Durys Elżbieta, Amerykańskie popularne kino policyjne w latach 1970-2000, Wydawnictwo Uniwersytetu Łódzkiego, Łódź 2013.

Lubelski Tadeusz, Historia kina polskiego. Twórcy, filmy, konteksty, Wydawnictwo Videograf II, Chorzów 2009.

Ostaszewski Jacek, Stużyć, chronić i..., czyli filmy o policjantach, [w:] Wokót kina gatunków, red. Krzysztof Loska, Wydawnictwo Rabid, Kraków 2001.

Przylipiak Mirosław, Szyłak Jerzy, Kino najnowsze, Wydawnictwo Znak, Kraków 1999.

Wajda Katarzyna (KW), hasło: policyjny film, [w:] Encyklopedia kina, red. Tadeusz Lubelski, Wydawnictwo Biały Kruk, Kraków 2003.

\section{Czasopisma}

Korczarowska-Różycka Natasza, Ballada o pobożnym ubeku, czyli polskie kino i polityka (19892015), „Dyskurs. Pismo Naukowo-Artystyczne ASP we Wrocławiu” 2016, nr 21, s. 242-271.

Lis Piotr, Moralitet z klocków, „Kino” 1993, nr 5.

Wajda Andrzej, Pojedynek z dniem dzisiejszym. Rozmowa z Tadeuszem Sobolewskim, "Kino” 1993, nr 4.

Żurawiecki Bartosz, Czerwony Kapitan (recenzja), „Kino” 2016, nr 8.

\section{Streszczenie}

Artykuł jest analizą porównawczą dwóch filmów mających za bohatera pracownika dawnych, komunistycznych służb specjalnych, który w nowych okolicznościach geopolitycznych zostaje policjantem. Polskie Psy (1992) oraz słowacko-czeski Czerwony Kapitan (2016), mimo że zrealizowane $\mathrm{w}$ różnym okresie, przedstawiają protagonistę w momencie przełomu ustrojowego. Ich zestawienie, koncentrujące się na opisie trzech elementów ich poetyki - przestrzeni, wykorzystywanym gatunku oraz bohaterze, pozwala ujrzeć ich specyfikę, związaną z odwołaniami do filmu policyjnego (Psy) oraz literatury i kina noir (Czerwony Kapitan), a także różne powody, dla których filmy te powstały. 